\title{
The Impact of work motivation on Employee's Job Satisfaction in different Organizations *
}

\author{
Faraydoon M. Mahmood \\ Department of Administration, College of Administration and Economics, University of Human Development, Al- \\ Sulaymaniah, Iraq \\ faraydoon.mahmood@uhd.edu.iq
}

\begin{abstract}
The research made an attempt to explore the relationship between job satisfaction and work motivation. Job satisfaction has been treated as an independent and motivation as a dependent variable. The participators were the employees of different offices in Sulaymaniyah - Kurdistan. The data has been collected from 41 employees. Researcher collected primary data and used two different types of standard questionnaires. Findings provide that job satisfaction has affected by motivation.
\end{abstract}

\section{INTRODUCTION}

There are many studies which explored the existing trend on job satisfaction and work motivation around the world. Copious researchers agreed on their finding that job satisfaction was dependent on work motivation. The relevance of job satisfaction and motivation are very crucial to the long-term growth of any organization around the global. Job satisfaction contains positive influence on the performance of the employees as it enhances job involvement and the higher performance also makes people feel more satisfied and committed to the organization. Motivation is the process that arouses, energizes, directs, and sustains behavior and performance. Motivation encourage people internally towards the actions which helps them to achieve a preferred task employ effectiveness is a way which can inspire people to their work and can bring more work motivation to their commitment of their jobs. This paper aims to examine the impact of work motivation on employee job satisfaction in different organizations.

\section{A. Research objectives}

To study the relationship between employees' work motivation and employees' Job satisfaction in different organizations.

\section{B. Research Question}

To what extent does the job satisfaction influenced by work motivation?

\section{LITERATURE REVIEW}

\section{A. Introduction}

Review of literature was supported to report the studies related to Work motivation and Job satisfaction. Following studies considered the underlying phenomena and relationship between Work motivation and Job satisfaction which provide a basis to find out the research gap for the current study.

\section{B. Work Motivation}

Motivation is the process that directs, energizes, arouses, and sustains behavior and performance. People have encouraged internally towards the actions by motivation which helps them to attain a preferred task employ effectiveness is a way which can stimulate people to their work and can bring more work motivation to their commitment of their jobs (Saleem et al 2010).

Simon (1997) pointed out clearly in his study, why motivation is mandatory? The basic confront for all organizations today, are to achieve their organizational goals through motivates their staff. However, Pfeffer (1998) has also shown his findings in his study that, the companies that had learned the methods of how to utilize and manage their employees would be victorious in long term. In addition, also know how to organize importance of work and having satisfied people in their company is a way to organizational effectives.

\section{Job satisfaction}

There are many commonly used definitions for job satisfaction (Sempane et al., 2002). According to (Ellickson, 2002) who has defined job satisfaction as the extent to which employees like their work. Job satisfaction is a stance that people have about their job and the organization in which they work $(\operatorname{Rad} \&$ Yarmohammadian, 2006).

Two general categories associated with job satisfaction have identified by Ellickson (2002) which are personal factors and environmental factors. Personal factors refer to individual attributes and characteristics, while environmental factors pertain to the work itself or work environment (Ellickson, 2002). Under the personal characteristics factors like gender, age and job level were identified as variables by (Ellickson, 2002). 
For the environmental factor, the variables like opportunities for promotion, pay, fringe benefits, work resources, sufficient work space, safe work environment, training opportunities, evenly distributed workloads, relationship with one's supervisor, performance appraisal and departmental pride were identified. The outcomes of Ellickson (2002) were that promotional opportunities, pay benefits were rated as most significant to job satisfaction. Ellickson (2002) also found that age and gender had no effect in predicting job satisfaction.

\section{Relation between Work Motivation and Job Satisfaction}

According to Carlyle's Great Man Theory (1988) achievements of an organization are its achievements of employee. This theory provides how important staffs are for an organization and how important it is that they are motivated, satisfied, and hence productive. As it is a well-known fact that these two factors like, Job satisfaction and motivation have a significant impact on the performance of a staff and organization as well, thus, the analyse of relationship between these two variables unarguably becomes a topic of prime importance and of significant interest for research and further study.

According to study done by Ilies and Judge (2003) on job satisfaction, employees who tend to be positive and delight most of the time do indeed tend to express higher job satisfaction than others who tend to be Gloomy and Down. They also mentioned that job satisfaction mainly depends on the match between the results of individual value in their jobs and their perceptions about the availability of such results-especially for those factors of the job that are highly valued.

Gupta and Joshi (2008) have pointed the influence and the connection between the job contentment and work inspiration for the workers. Productivity in the work of a worker is result of satisfaction and productivity can be taken as indicator of satisfaction. Workers have to spend most of their time at workplace and need satisfaction at that place. Kovach (1987) has tried to describe the relationship between work motivation and job satisfaction; the need to provide the basic necessities of life motivates most people which in return make the staffs satisfied from their jobs. While Brown (1996) studies that when an organization is having some delighted or satisfied staffs, it is probable to have delighted or satisfied customers. Brown believed the staff delightedness and satisfied as a prerequisite of consumer satisfaction. Therefore, Wagar (1998) clarified that in the international market, one can be successful when it has highly motivated, expert, and satisfied workforce that can create quality goods at low costs.

\section{E. Hypothesis}

This research was conducted to test the following hypothesis:

H1: Employee Work Motivation has direct positive effect on Job Satisfaction.

\section{ReSEARCH MethodolOGY}

Keeping in mind what academics have argued in their work with relation on the influence of work motivation on job satisfaction of employee, this research is been designed and the study is been conducted to have a clear vision of the relationship. In this research, job satisfaction is been examined through the change in work motivation. A questionnaire was designed to collect the required data for motivation and satisfaction. The descriptive statistics was used to analyze data including mean, median and standard deviation. Analysis of regression was implemented to examine the impact of work motivation on job satisfaction of employees.

A. Population

The population of this research is employees in several offices in Sulaymaniyah - Kurdistan which are selected randomly.

B. Sample and Response Rate

One hundred questionnaires were distributed to those employees, but 41 of them were responded.

C. Description of the Instrumentation Questionnaire - to find the answer of employees concerning work motivation and job satisfaction Work motivation - the Independent variable Job satisfaction - the dependent variable Case- Employees

An amendment questionnaire identified work motivation, and job satisfaction scale (WMJSS) was utilized for the collection of data on the research. The questionnaire was exactly designed to achieve the objectives of the research. Information such as age, sex, and qualification were collected by the first part. The second part included the items, and was separated into two parts;

Part 1; this measures job satisfaction, which included 7 questions. The item was adopted from job satisfaction, Cook et al. (1981).

Part 2; this measures work motivation, which included 8 questions. The item was adopted from work motivation, Saleem et al. (2010).

6-item-Likert scale was used for both sections which ranging from Strongly Agree; Agree; somewhat agree; Somewhat Disagree; Disagree; and Strongly Disagree.

D. Pilot Testing

The questionnaires were distributed to tow employees of Sulaymaniyah statistic office and got the reply from them. The researchers have improved the questionnaire consequently and consulted other people for support.

\section{E. Data Collection}

One hundred questionnaires of hard copy were distributed to employees by hand to hand, but forty-one employees have been responded.

\section{F. Data Analysis}

IBM SPSS Statistics 21 and MS-Excel 2010 were applied to get the outcomes. Means and Standard Deviations was considered, that provided us a wider view of the data, how much people are satisfied and up to what extend the psychology of employees differ in a work environment. Regression Analysis was approved to 
determine the effect of independent variables on dependent variables.

\section{RESEARCH FINDINGS}

\section{A. Employees' attitudes to Job Satisfaction}

The employee's attitudes about job satisfaction is illustrated in table (1) they have six

Table 1 Employees' Attitudes about Job Satisfaction

\begin{tabular}{|c|c|c|c|c|c|}
\hline No & Questions & $\mathrm{N}$ & $\begin{array}{c}\text { Mea } \\
\mathrm{n}\end{array}$ & $\begin{array}{l}\text { Std. } \\
\text { Devia } \\
\text { tion }\end{array}$ & Attitudes \\
\hline 1 & $\begin{array}{l}\text { I am often } \\
\text { bored with } \\
\text { my job }\end{array}$ & 41 & 3.20 & 1.400 & $\begin{array}{c}\text { Somewhat } \\
\text { agree }\end{array}$ \\
\hline 2 & $\begin{array}{c}\text { I feel fairly } \\
\text { well satisfied } \\
\text { with my } \\
\text { present job }\end{array}$ & 41 & 4.63 & 1.157 & agree \\
\hline 3 & $\begin{array}{l}\text { Most days I } \\
\text { am } \\
\text { enthusiastic } \\
\text { about my } \\
\text { work }\end{array}$ & 41 & 4.71 & 1.327 & agree \\
\hline 4 & $\begin{array}{l}\text { I find real } \\
\text { enjoyment in } \\
\text { my work }\end{array}$ & 41 & 4.51 & 1.416 & agree \\
\hline 5 & $\begin{array}{l}\text { I am satisfied } \\
\text { from the } \\
\text { recognition I } \\
\text { get for good } \\
\text { work }\end{array}$ & 41 & 3.63 & 1.920 & $\begin{array}{c}\text { Somewhat } \\
\text { disagree }\end{array}$ \\
\hline 6 & $\begin{array}{l}\text { I am satisfied } \\
\text { from the } \\
\text { chances of } \\
\text { promotion }\end{array}$ & 41 & 3.95 & 1.658 & $\begin{array}{c}\text { Somewhat } \\
\text { agree }\end{array}$ \\
\hline 7 & $\begin{array}{l}\text { I am satisfied } \\
\text { with the } \\
\text { amount of } \\
\text { variety in my } \\
\text { job }\end{array}$ & 41 & 4.12 & 1.364 & $\begin{array}{c}\text { somewhat } \\
\text { agree }\end{array}$ \\
\hline
\end{tabular}

B. Employees' attitudes to Work Motivation

The employee's attitudes about work motivation is illustrated in table 2 they have six Choices from strongly agree, (1_1.83), Agree (4.33_5.16), Somewhat Agree (3.5_4.3), Somewhat Disagree (2.6_3.5), Disagree (1.83_2.66), to strongly disagree (2.6_3.5) about various questions. Moreover, the table 1, 2 have shown mean and standard deviations for job satisfaction and work motivation which are $(4.10$ _ 4.64) and (1.46_1.28) respectively.
Table 2 Employees' Attitudes about Work Motivation

\begin{tabular}{|c|c|c|c|c|c|}
\hline No & Questions & $\mathrm{N}$ & Mean & $\begin{array}{c}\text { Std. } \\
\text { Deviation }\end{array}$ & Attitudes \\
\hline 1 & $\begin{array}{l}\text { I arrive at } \\
\text { the office on } \\
\text { time and do } \\
\text { not leave } \\
\text { early }\end{array}$ & 41 & 4.98 & 1.084 & agree \\
\hline 2 & $\begin{array}{l}\text { The work I } \\
\text { do is } \\
\text { interesting. }\end{array}$ & 41 & 4.88 & 1.345 & agree \\
\hline 3 & $\begin{array}{c}\text { I am } \\
\text { confident of } \\
\text { my abilities } \\
\text { to succeed at } \\
\text { my work }\end{array}$ & 41 & 5.44 & .594 & $\begin{array}{l}\text { strongly } \\
\text { agree }\end{array}$ \\
\hline 4 & $\begin{array}{l}\text { I do not } \\
\text { blame others. } \\
\text { I take } \\
\text { responsibility } \\
\text { for my part } \\
\text { in mistakes }\end{array}$ & 41 & 4.66 & 1.389 & Agree \\
\hline 5 & $\begin{array}{c}\text { I have a } \\
\text { coach/mentor } \\
\text { who keeps } \\
\text { me alert \& } \\
\text { motivated to } \\
\text { my work }\end{array}$ & 41 & 3.54 & 1.719 & $\begin{array}{c}\text { somewhat } \\
\text { disagree }\end{array}$ \\
\hline 6 & $\begin{array}{c}\text { I expect } \\
\text { more } \\
\text { accuracy in } \\
\text { my own } \\
\text { work as my } \\
\text { employees }\end{array}$ & 41 & 5.10 & .735 & Agree \\
\hline 7 & $\begin{array}{l}\text { I regularly } \\
\text { think/worry } \\
\text { about work } \\
\text { issues when I } \\
\text { am at home }\end{array}$ & 41 & 4.02 & 1.877 & $\begin{array}{c}\text { somewhat } \\
\text { agree }\end{array}$ \\
\hline 8 & $\begin{array}{l}\text { I participate } \\
\text { in training to } \\
\text { improve my } \\
\text { own skills } \\
\text { and } \\
\text { competencies }\end{array}$ & 41 & 4.56 & 1.550 & Agree \\
\hline
\end{tabular}

Sourse: Author

\section{Descriptive Statistics}

Table 3 demonstrations the correlations of all study variables. Age, sex, and certification were no related to both job satisfaction and work motivation $(\mathrm{p}<.01)$. However, the availability of work motivation was significantly and positively related to job satisfaction ( $\mathrm{p}<$ $.05)$. 
Table 3: Correlation

\begin{tabular}{|c|c|c|c|c|c|}
\hline & $\begin{array}{c}\text { Sex } \\
\text { dlassification } \\
\end{array}$ & $\begin{array}{c}\text { centificate } \\
\text { dessificstion }\end{array}$ & $\begin{array}{c}\text { Ace } \\
\text { dassificasion }\end{array}$ & $\begin{array}{c}\text { Work } \\
\text { Moiraton }\end{array}$ & $\begin{array}{c}\text { Job } \\
\text { Sattifacton }\end{array}$ \\
\hline \multirow{3}{*}{$\begin{array}{l}\text { Pess on Carelstion } \\
\text { sex desss ricaton } \\
\text { Sig. |2-tsilec| }\end{array}$} & 1 & -015 & $\therefore 175$ & .049 & 224 \\
\hline & & .526 & 274 & .763 & 159 \\
\hline & 41 & 44 & & 41 & 41 \\
\hline \multirow{2}{*}{$\begin{array}{l}\text { Pers on Carelstion } \\
\text { certif cate clas ifisation }\end{array}$} & -.015 & 1 & .082 & -.14 & -124 \\
\hline & .926 & & .609 & .477 & .442 \\
\hline \multirow[t]{2}{*}{ N } & 41 & 41 & 41 & 41 & 41 \\
\hline & -.175 & .032 & & -.016 & -218 \\
\hline $\begin{array}{l}\text { Peas on Carelstion } \\
\text { Age classiffation }\end{array}$ & .274 & .639 & 1 & .919 & .171 \\
\hline Sig. [2-tsilec] & 41 & 41 & 41 & 41 & 41 \\
\hline \multicolumn{6}{|l|}{$\mathrm{N}$} \\
\hline & .049 & -.114 & -.016 & 1 & $.537^{* *}$ \\
\hline & .763 & .477 & .919 & 41 & .000 \\
\hline $\begin{array}{l}\text { Peasson Carelstion } \\
\text { Work Motiation }\end{array}$ & 41 & 41 & 41 & & 41 \\
\hline \multicolumn{6}{|l|}{ Sig. |2-tailec; } \\
\hline \multicolumn{6}{|l|}{ N } \\
\hline $\begin{array}{l}\text { Pess on Carelstion } \\
\text { ich s stitstaction }\end{array}$ & .224 & -.124 & -.218 & $.537^{* \star}$ & 1 \\
\hline Sig. |2-tsilec| & .59 & .442 & .171 & .000 & 41 \\
\hline $\mathrm{N}$ & 41 & 41 & 41 & 41 & \\
\hline
\end{tabular}

*. Correlaior is significant at the 0.01 level (2-tailed).

\section{Testing Hypotheses}

To exam our hypotheses, we conduct a series of hierarchical regression analyses. In the first step job satisfaction as a depended variable entered and work motivation as an independent variable entered in the second step. Tables 4 show the variables included in each step for work motivation and job satisfaction, respectively. In support of $\mathrm{H} 1$, we found that the availability of work motivation significantly, predicted job satisfaction, $\mathrm{F}(15.84)=1, \mathrm{p}<.001$, total $\mathrm{R} 2=963.8$ with work motivation positively related to and contributing uniquely to job satisfaction $\beta=.53, \quad \mathrm{p}<$ $.01, \mathrm{R} 2=.35, \mathrm{p}<.01$.

Table 4: Regression

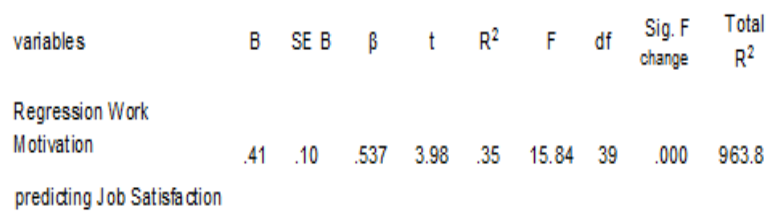

\section{CONCLUSION AND DISCUSSION}

Employees are always the important resource of the organization. Beside this, sometimes they are ignored at their jobs which lead to their failure to perform.
Therefore, here we need to know what motivates employees and how they become satisfied from their job leads to organizational performance. Motivation might be defined as a driving force that makes employees cheerfully want to put in their best in what they do. As many researchers believed that motivation leads to an increase performance of employee into other level and eventually the positive influence goes toward company's recital. Furthermore, researcher can study that motivation is also an understood compliment towards job satisfaction of employee. Job satisfaction expresses the employee more considerate and concerned for the organization.

In conclude, job satisfaction would be attained when an employee is motivated to do work by his or her own will. Thus, if organizations want to increase their profits so it must consider all sides to develop the system of employees.

A. Suggestion

To raise the job satisfaction level of the employees the institution should concentrate the following points:

- Ideal staffs should concentrate on their job.

- Institution must provide promotion to those employees who deserve it.

$B$. Limitations of Study

The limitations of this research have pointed out as follow:

- Small number of participants: only forty-one employees have been responded that was a small number to represent whole of the population.

- $\quad$ Short time period: this research has been carried out by the short time period; so many facts have been left unexplored.

- $\quad$ During this study the Kurdistan region was passing in the bad economic situation, employees have not paid for two months, and in researcher's opinion it was the main reason to this percentage $(41 \%)$ of respondent.

\section{References}

[1] Brown, Mark G. (1996). Keeping Score: Using the Right Metrics to Drive World-Class Performance. New York: Quality Resources.

[2] Carlyl Thomas, The Great Man Theory, On Heroes, HeroWorship and the Heroic in History, Fredrick A. Stokes \& Brother, New York, 1888. p. 2. Available at http://en.wikipedia.org/wiki/Great_Man theory (accessed on 09,Feb, 2015).

[3] Cook, J.D., Hepworth, S.J., Wall, T.D. \& Warr, P.B. (1981). The experience of work. San Diego: Academic Press.

[4] Ellickson, M.C. (2002). Determinants of job satisfaction of municipal government employees. Public personnel Management, 31(3), 343-358

[5] Gupta K. Shashi \& Joshi Rosy (2008). Human Resource Management, $\mathrm{Pg}$ (20.9 to 20.17)

[6] Ilies R. And Judge T.A (2003). On the heritability of Job Satisfaction: the mediating role of personality Journal of applied psychology, 88, 750-759.

[7] Kovach, K. (1987). What Motivates Employees? Workers and Supervisors Give Different Answers. Business Horizons.

[8] Pfeffer, J. (1998). The Human Equation: Building Profits by Putting People First. Cambridge, Mass: Harvard Business School Press. 
[9] Rad, A.M.M., \& Yarmohammadian, M.H. (2006). A study of relationship between manager's leadership style and employee's job satisfaction. Leadership in Health services, 19(2), xi-xxviii.

[10] Saleem et al (2010). Effect of Work Motivation on Job Satisfaction in Mobile Telecommunication Service Organizations of Pakistan, Vol. 5, No. 11.

[11] Saleem, R., Mahmood, A., Mahmood, A. (2010). Effect of Work Motivation on Job Satisfaction in Mobile Telecommunication Service Organizations of Pakistan. International Journal of Business and Management. Vol. 5, No. 11; November 2010.

[12] Sempane, M.E., Riegerm H.S., \& Roodt, G. (2002). Job satisfaction in relation to organization culture. South African Jounal of Industrial Psychology, 28(2), 23-30.

[13] Simon, H (1997). Administrative Behavior: A Study of Decision-Making Processes in Administrative Organizations, 5th edition. New York, NY: Macmillian Company.

[14] Wagar, Terry H. (1998). Determinants of Human Resource Management Practices in Small Firms: some Evidence from Atlantic Canada. Journal of Small Business Management.

\section{Appendix: Questionnaire:}

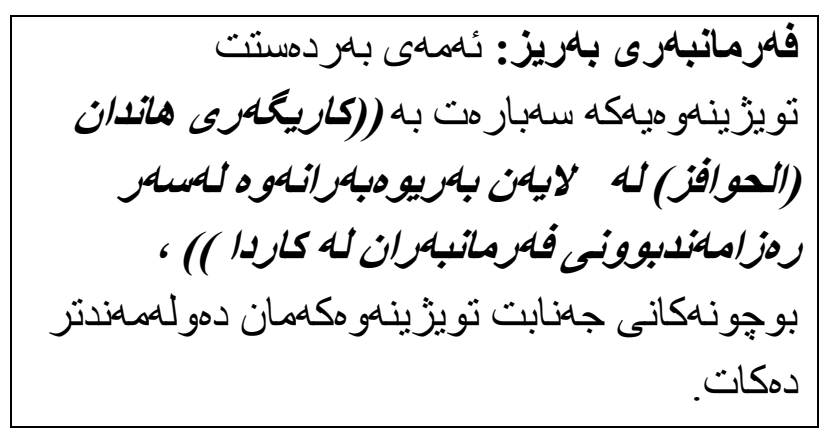
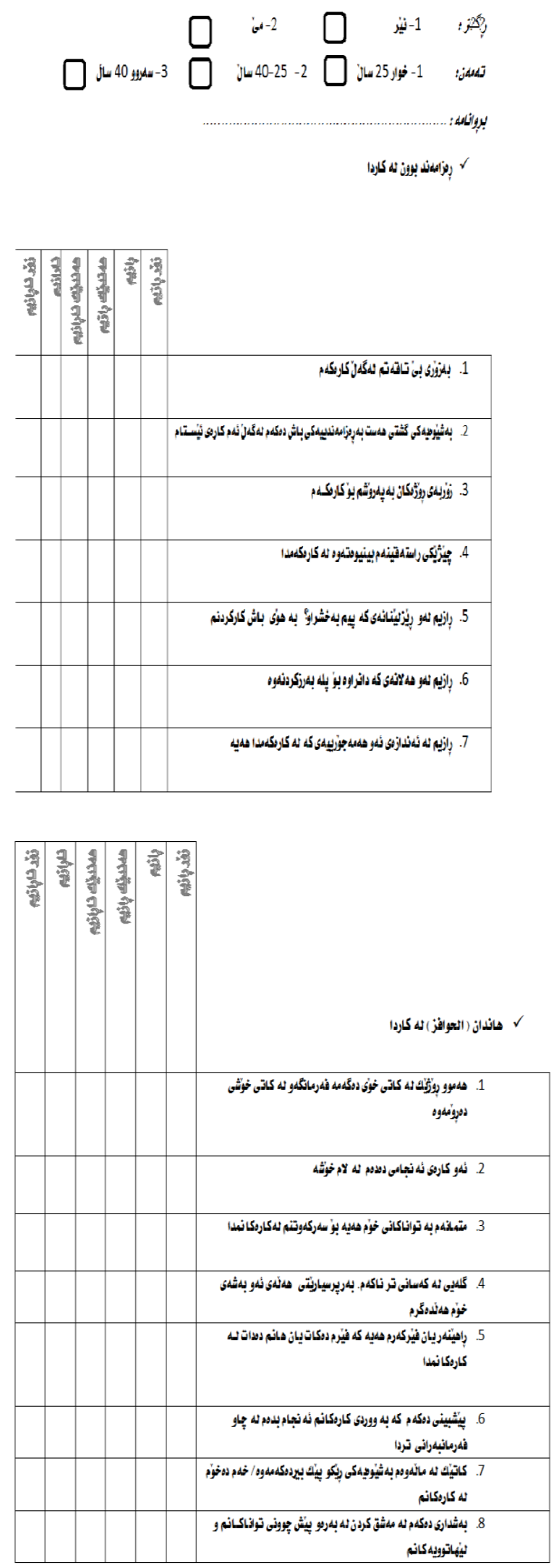